\title{
O impacto dos ativos intangíveis no valor da empresa
}

\author{
The Impact of Intangibles on Corporate Value
}

\author{
Fabienne Torres Schiavo ${ }^{1}$
}

\section{Resumo}

Ao mesmo tempo que os ativos intangíveis têm sido amplamente discutidos e apresentados como condutores de sucesso, ainda são poucas as reflexões sobre a influência destes ativos no valor das empresas. Este trabalho surge, portanto, com o objetivo de identificar uma maneira de se contemplar os ativos intangíveis no valor de uma empresa, quando a mesma é avaliada pelo método de Fluxo de Caixa Descontado. A partir desta metodologia foram analisadas como os intangíveis marca, reputação, redes e alianças estratégicas, tecnologias e processos, capital humano, capital intelectual, inovação, adaptabilidade, cultura organizacional, liderança, responsabilidade socioambiental, e comunicação e transparência podem impactar o valor da empresa, e como eles relacionam-se entre si. Este trabalho resume a dissertação apresentada como conclusão do curso de Mestrado em Administração Pública pela Escola Brasileira de Administração Pública da Fundação Getúlio Vargas (EBAPE-FGV).

Palavras-chave: intangíveis, sustentabilidade, valor das empresas

\begin{abstract}
Intangibles assets have been widely discussed and presented as corporate successful conductors. At the same time, there are still few suggestions of how they can affect company value. This work has as main goal identify a way of considering intangibles assets when valuating companies through Discounted Cash Flow methodology. Twelve intangibles - brand, reputation, strategic alliance, human capital, intellectual capital, innovation, adaptability, corporate environment, social and environmental responsibility, leadership and communications and transparency - , were analyzed in order to find how they influences corporate economic value, and how they influence one another. This article sums up the thesis presented as final project at the Master of Public Administration at Fundação Getulio Vargas (FGV).
\end{abstract}

Keywords: intangibles, sustainability, corporate economic value

\section{Introdução}

A relevância dos ativos intangíveis ganha cada vez mais destaques nos discursos empresariais. Por um lado, há uma crescente insatisfação com a relevância e utilidade das informações dos relatórios financeiros, principalmente entre investidores e executivos de empresas. Insatisfação essa corroborada por uma lacuna crescente entre os indicadores do mercado de capitais e as informações financeiras, mais ainda os ganhos reportados (BARUCH, 2018). Nessa mesma linha, uma crítica comum às abordagens de avaliação de empresas, em geral, e aos analistas financeiros, em particular, é que pouca atenção é dada aos ativos intangíveis (DAMODARAN, 2007). Por outro lado, é igualmente crescente

\footnotetext{
${ }^{1}$ Mestre em Administração Pública. Fundação Getúlio Vargas (FGV) - Brasil. E-mail: fabienne.schiavo@gmail.com
} 
a quantidade de artigos e livros que mencionam que na economia atual a vantagem competitiva costuma aumentar não para empresas com as melhores fábricas ou com maior capital, mas aquela que faz o melhor trabalho de administração de seus intangíveis. Ou seja, no século XXI não há com. o negligenciar o fato de que os intangíveis estão transformando a forma como se administra um negócio, gerencia-se as pessoas, cria-se produtos, vende-se serviços e se interage com os clientes (KALAFUT \& LOW, 2003).

Os ativos intangíveis estão relatados em relatórios anuais de grandes corporações. Os balanços sociais e ambientais também refletem a preocupação das empresas com os investimentos em intangíveis. Junto com outros instrumentos de governança corporativa, eles trazem informações cuja análise, assim como as das demonstrações financeiras, podem afetar a percepção de seus públicos acerca da empresa e seu papel social, o que em alguns mercados já influencia o seu valor acionário. Já se identifica, ainda que de forma bastante tímida, a existência de investidores que buscam aliar seus valores e preocupações sociais aos objetivos de obter retorno financeiro, escolhendo empresas que julgam cumprir com o desenvolvimento sustentável - econômico, social e ambiental. A preocupação com os intangíveis atinge também o mercado de ações.

Os índices de sustentabilidade, como o Dow Jones Sustantability Index (DJSI) da Dow Jones e o Índice de Sustentabilidade Empresarial (ISE) da Bovespa buscam, de certa forma, quantificar esses ativos a partir dos critérios adotados para avaliar empresas comprometidas com políticas socioambientais consideradas corretas e saúde financeira comprovada. Esses critérios incluem, por exemplo, qualidade de gestão, transparência, conduta, planejamento estratégico, capital intelectual, reputação, riscos e crises, gestão ambiental, comunicação com partes interessadas, compromisso global, política socioambiental e relacionamento com público interno, comunidade, fornecedores e clientes.

Mas mesmo diante de evidências concretas, o que se observa é que, atualmente, ainda não há registros de uma medição de resultados de investimento em ativos tangíveis e intangíveis que possibilite uma correlação entre ambos, uma análise da influência que um pode exercer sobre o outro, ou o impacto de ambos no desempenho da organização. Como consequência dessa ausência surgem necessidade de respostas para algumas questões, como:

- Quanto do valor da empresa pode ser atribuído aos intangíveis? Essa questão vem sendo discutida há anos e em diferentes setores. Uma frase que ampliou essa discussão foi: "hoje o PIB real nos EUA pode ser $10 \%$ mais alto do que o governo diz que é simplesmente porque intangíveis como projetos, plantas, softwares, ideias, etc., não são calculados com precisão" (NAKAMURA, 2001).

- Como os intangíveis podem afetar o desempenho de uma empresa?

"As atuais estruturas econômica, estatística e contábil precisam urgentemente de atualização. Novos modelos explanatórios e novas métricas são necessários para permitir-nos entender o trabalho da economia moderna, especialmente nos setores de bens intangíveis e de "conteúdo" que estão atualmente escondidos da vista do público" (COMISSÃO EUROPÉIA, 2000) 
- Que proporções as empresas estão investindo nos intangíveis, uma vez que esses números não aparecem nos análises financeiras e demonstrações contábeis?

"Os modelos de valor presente utilizados por investidores e credores para avaliar empresas são inadequados frente aos ativos intangíveis as empresas avaliadas, por sua vez, comunicam muito poucas informações sobre esses ativos" (HOFMANN, 2005)

Dos argumentos expostos emerge a seguinte questão, que define o problema de pesquisa do presente projeto: de que forma os ativos intangíveis impactam o valor de uma empresa?

\section{Metodologia}

A classificação da pesquisa foi baseada na taxionomia apresentada por Vergara (2006), que propõe dois critérios básicos: quanto aos fins e quanto aos meios.

Quanto aos fins, a pesquisa foi exploratória, metodológica e aplicada. Exploratória porque, embora haja muitas teorias acerca das avaliações de empresas e de ativos intangíveis, esses materiais foram desenvolvidos isoladamente e possuem caráter descritivo. Não se verificou estudos que buscassem uma conexão entre os dois assuntos, e nem formas de mensuração que contemplem os simultaneamente os dois. Metodológica porque apresentou como objetivo desenvolver um novo sistema de medição capaz de demonstrar o impacto dos ativos intangíveis no valor de uma empresa. E aplicada porque, ao contrário da pesquisa situada no nível da especulação, tem finalidade prática.

Quanto aos meios a pesquisa foi bibliográfica, experimental e ex post facto. Bibliográfica porque foi necessária uma composição prévia de um referencial analítico, desenvolvido com base em material publicado em livros, revistas, jornais, redes eletrônicas, relatórios empresariais e qualquer outro tipo de material acessível ao público em geral, que viabilizará a realização da pesquisa. Experimental porque foram avaliadas as variações das variáveis que permitem manipulação. Ex post facto porque muitas variáveis sob análise não são controláveis e manipuláveis.

O universo da pesquisa foi formado por empresas, tanto privadas quanto públicas, que aparecem em estudos que contemplem a gestão de intangíveis. A amostra foi definida pelo critério de acessibilidade e restringe-se às empresas brasileiras que disponibilizaram seus laudos de avaliação submetidos a Comissão de Valores Mobiliários (CVM) e/ou empresas que compõem o Índice de Sustentabilidade Empresarial da Dow Jones. Assim, foram analisados os laudos de avaliação submetido CVM das seguintes empresas: Dana- Albarus S.A. Indústria e Comercio (realizado pelo HSBC em março de 2005); Aços Villares S.A. (realizado pelo Itaú, em fevereiro de 2006); Copesul (realizado pela Calylon em abril de 2007); Arcelor Brasil S.A. (realizado pela Goldman Sachs International em outubro de 2006); e Bunge Brasil SA. (realizado pelo Credit Suisse em maio de 2004). A escolha desses laudos obedeceu ao seguinte critério: avaliações feitas em anos deferentes e por instituições financeiras diferentes (Itaú, Credit Suisse, Goldman Sachs, HSBC e Calylon). 
No que se refere aos intangíveis, o estudo abrangeu doze ativos: marca, reputação, redes e alianças estratégicas, tecnologias e processos, capital humano, capital intelectual, adaptabilidade, inovação, organização e cultura do ambiente de trabalho, liderança, responsabilidade social e ambiental e comunicação e transparência.

Para analisar de que forma os ativos intangíveis impactam o valor de uma empresa, a primeira etapa foi investigar como uma empresa é avaliada. Na sequência buscou-se relacionar os intangíveis com a metodologia de Fluxo de Caixa Descontado, de modo que fosse possível visualizar a presença destes ativos na avaliação de uma empresa. Por fim, foram analisados os doze ativos intangíveis, a relação entre eles e o impacto positivo ou negativo que eles podem ter sobre o valor das empresas.

\section{Resultados}

Para analisar de que forma os ativos intangíveis impactam o valor de uma empresa, a primeira etapa foi investigar como uma empresa é avaliada. Como se chega a um valor a respeito de uma determinada empresa? Que variáveis são levadas em consideração?

Segundo Damodaran (2001), um ativo é qualquer recurso que tem potencial de gerar fluxos de entrada ou de reduzir fluxos de saída de caixa futuro. Sob a ótica da contabilidade, para um recurso ser considerado um ativo, a empresa precisa tê-lo adquirido em uma transação passada e ter condições de quantificar os benefícios futuros com o máximo de precisão que estiver ao seu alcance. Assim, o valor do ativo está baseado em seu custo histórico, isto é, o custo original do ativo, ajustado paralelamente às melhorias realizadas a partir da data de sua aquisição e às perdas associadas ao seu envelhecimento. Esse custo histórico é o valor contábil do ativo. Mas, se os ativos caracterizam-se como recursos capazes de gerar fluxos de caixa futuros, fazem parte desse grupo, por exemplo, funcionários leais que produzem soluções inovadoras, marcas fortes capazes de fidelizar clientes, sistemas de tecnologia de informação que reduzem custos operacionais e outros ativos intangíveis que não se pode definir com precisão uma data de origem ou seu valor de aquisição. Qual seria o valor original de um cliente fiel, de uma fórmula descoberta após anos de investimento em pesquisa ou de um novo sistema de gestão desenvolvido?

Para o cálculo do valor das empresas existem diferentes métodos e modelos (quadro 1), que por sua vez buscam atender diferentes premissas. As causas que levam aos diferentes resultados encontrados podem ser atribuídas aos seguintes fatores: além de cada um apresentar em sua base de cálculo itens específicos, também afetam o valor final a obtenção de dados corretos e sua interpretação, e as incertezas associadas às estimativas de cada caso. É importante ressaltar que, devido ao fluxo constante de informações nos mercados financeiros e outras fontes disponíveis, as avaliações podem ficar obsoletas, o que requer atualizações e revisões frequentes.

\begin{tabular}{|l|l|}
\hline \multicolumn{2}{|c|}{ Métodos de avaliação de empresas: } \\
\hline 1. Balanço Patrimonial & $\begin{array}{l}\text { - Modelo do valor contábil } \\
\text { - Modelo do valor contábil ajustado }\end{array}$ \\
\hline
\end{tabular}




\begin{tabular}{|l|l|}
\hline & - Modelo do valor de liquidação \\
& - Modelo do valor substancial \\
\hline 2. Resultado econômico & - Modelo do valor dos lucros \\
& - Modelo do valor dos dividendos \\
& - Modelo dos múltiplos de vendas \\
& - Outros modelos de múltiplos \\
\hline 3. Misto (Goodwill) & - Modelo clássico \\
& - Modelo simplificado da União Européia \\
& - Modelo dos peritos contábeis europeus \\
& - Método indireto \\
& - Método de compras de lucros anuais \\
& - Modelo da taxa de risco relativo e de risco livre \\
\hline 4. Fluxo de Caixa Descontado & - Fluxo de caixa livre \\
& - Equity cash flow \\
& - Capital de cash flow \\
& - Modelo de dividendos \\
& - Adjusted Present Value (APV) \\
\hline 5. Criação de valor & - Economic Value Added (EVA) \\
\hline & - Cash Flow Return on Investment (CFROI) \\
\hline 6. Outros & - Black \& Scholes \\
& - Opções de investimentos \\
& - Expansão de projetos \\
& - Adiamento de investimento \\
& - Usos alternados \\
\hline
\end{tabular}

Quadro 1: métodos e modelos de avaliação de empresas

Fonte: FERNANDEZ, 2001

Os métodos baseados no Fluxo de Caixa Descontado a Valor Presente, em particular no método de fluxo de caixa livre, têm sido os mais adotados como base de cálculo do valor econômico de uma empresa e representam aproximadamente $55 \%$ da preferência de utilização (BALDIN, D.). Este foi o método analisado no âmbito desse trabalho.

Para a finalidade deste trabalho, após as análises iniciais, dois pontos a respeito da avaliação de empresas foram destacados: a lacuna existente entre o valor contábil e o valor econômico e as variáveis gerenciáveis no cálculo a partir do Fluxo de Caixa Descontado.

Sobre a lacuna, de acordo com o Índice Mundial da Morgan Stanley, o valor das empresas cotadas na bolsa de valores é, em média, o dobro do seu valor contábil (SCHMIDT E SANTOS, 2001:9), o que abre uma oportunidade para se discutir como os ativos intangíveis podem influenciar o valor de mercado da empresa. Segundo Schmidt e Santos (2002:9), esses hiatos têm crescido de forma assustadora, em função da relevância assumida pelos ativos intangíveis em relação aos ativos tangíveis na composição do patrimônio das entidades". Essa diferença é atribuída aos intangíveis e denominado por muitos como goodwill.

De forma abrangente, o goodwill pode ser entendido como "aquele algo mais pago sobre o valor de mercado do patrimônio líquido das entidades adquiridas, devido a 
expectativa (subjetivas) de lucros futuros além de seus custos de oportunidade, resultante da sinergia existente entre as entidades" (SCHMIDT e SANTOS, 2002: 45).

Contabilmente o goodwill justifica a diferença entre o valor contábil e o valor de mercado de uma empresa. No entanto, na avaliação de empresas por Fluxo de Caixa Descontado, que antecede uma negociação, venda ou abertura de capital, ou funciona como instrumento de gestão para incremento do valor, o goodwill por si só não tem relevância. A empresa precisa identificar claramente quais intangíveis estão valorando ou diminuindo seu valor, um a um, para se que possa trabalhar para potencializar suas vantagens competitivas e/ou neutralizar suas fraquezas. Sobre essa questão, Damodaran afirma que:

\footnotetext{
"Não se trata de um ativo, mas de uma variável plug. Note que ele aparece somente após as aquisições e destina-se a captar a diferença entre o que é pago para uma empresa-alvo e o valor contábil de seus ativos, permitindo assim que o balanço patrimonial ainda apresente saldo após a aquisição. (...) embora seja pedir demais, o nosso trabalho de avaliação seria muito mais simples se o item goodwill nos balanços patrimoniais fosse decomposto." (DAMODARAN, 2001: 293).
}

Ou seja, contabilmente os ativos intangíveis aparecem como uma forma de justificar essa diferença.

A outra questão importante foi identificar as variáveis presentes do cálculo das empresas por Fluxo de Caixa Descontado que não dependem exclusivamente de fatores externos, isto é, que podem ser gerenciáveis, e verificar como cada uma delas pode impactar o valor final da empresa.

A figura 2 contém essas variáveis e ilustra como intervir para incrementar o valor final, ou seja, aumentar o valor dos fluxos de caixa e reduzir o valor do custo de capital. Assim, na avaliação da empresa por Fluxo de Caixa Descontado, percebe-se que as empresas podem interferir em apenas algumas variáveis utilizadas para calcular seu valor econômico (figura 2), sendo elas dependentes de fatores políticos, macroeconômicos e tributários. Dentre os itens que podem ser controlados pela empresa, deve-se buscar:
a) aumentar o faturamento
b) reduzir custos de venda
c) reduzir despesas operacionais
d) reduzir pagamentos de juros (alavancagem financeira)
e) reduzir investimentos em ativos fixos
f) aumentar capital de giro
g) reduzir custos fixos (alavancagem operacional)
h) avaliar a natureza do negócio
i) avaliar os pesos distribuídos entre capital próprio e capital de terceiros 

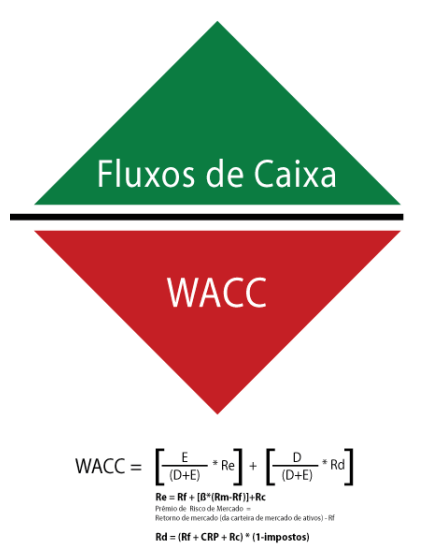

Năo deenende de ambiente externo

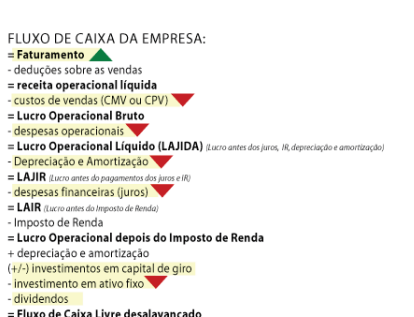

- dividendos
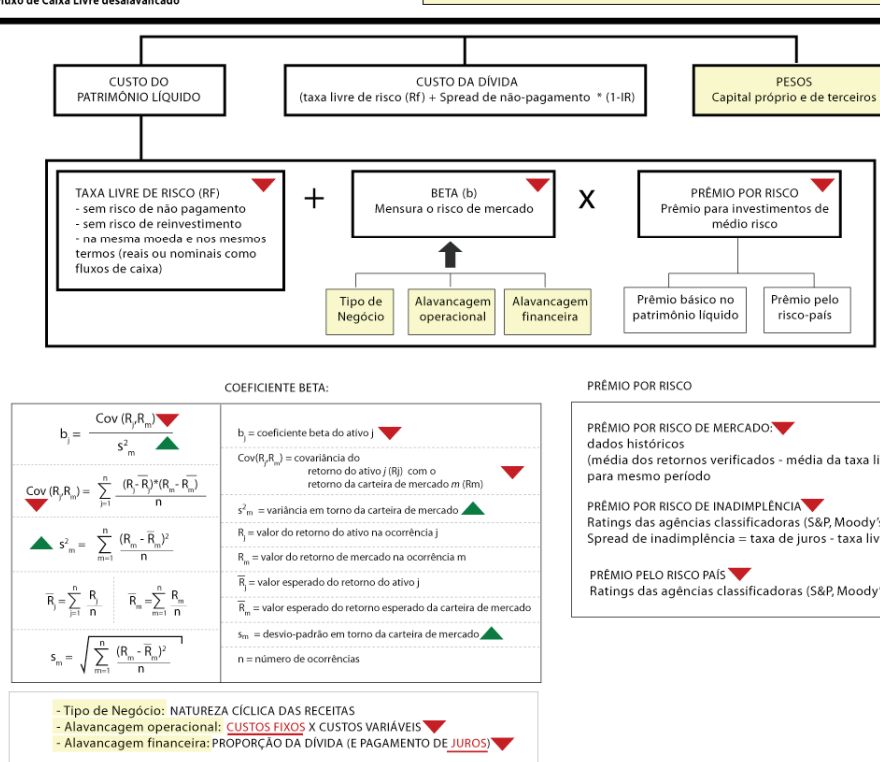

PREMIO POR RISCO PREMIO POR RISCO DE MERCADO $\checkmark$
dados histo

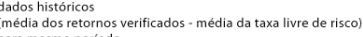
PREMIO POR RISCO DE INADIMPLENCIA Ratings das agências classificadoras (SRP, Moody's)
Spread de inadimplència = taxa de juros - taxa livre de risco

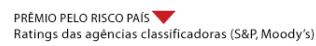

Figura 1: Avaliação de empresas por Fluxo de Caixa Descontado

Fonte: elaborado pela autora

A partir dessas analises, a etapa seguinte foi analisar como os intangíveis podem ser incorporados na avaliação das empresas e como podem ser trabalhados para incrementar seu valor. Os resultados estão apresentados no quadro 2.

\begin{tabular}{|l|l|}
\hline $\begin{array}{l}\text { Metas para de } \\
\text { incremento de } \\
\text { valor }\end{array}$ & Quais intangíveis contribuem para alcançar as metas (com exemplos) \\
\hline $\begin{array}{l}\text { a) aumentar o } \\
\text { faturamento }\end{array}$ & $\begin{array}{l}\text { - Marca: marcas fortes permitem que se cobre mais caro por produtos } \\
\text { semelhantes aos de seus concorrentes. Associações positivas com os valores } \\
\text { da marca contribuem com a fidelização do cliente } \\
\text { - Reputação: empresas com boa reputação têm maior credibilidade, o } \\
\text { influencia a tomada de decisão no ponto de venda, por exemplo. Em situações } \\
\text { de incerteza, as empresas com boa reputação se destacam } \\
\text { - Responsabilidade social e ambiental: os consumidores estão mais } \\
\text { conscientes e muitos deles já concordam em pagar mais por produtos de } \\
\text { empresas comprometidas com questões ambientais e sociais } \\
\text { - Inovação: produtos inovadores geram curiosidade, aumentam divulgação } \\
\text { informal e demoram mais a ter concorrentes } \\
\text { - Redes e alianças estratégicas: ao se unir com empresas de qualidade } \\
\text { reconhecida em setores complementares, as companhias agregam às suas } \\
\text { marcas atributos como qualidade e credibilidade das empresas parceiras, }\end{array}$ \\
\hline
\end{tabular}




\begin{tabular}{|c|c|}
\hline & $\begin{array}{l}\text { além de atraírem uma clientela já formada. Desta forma, ambas podem } \\
\text { ganhar (ex. Apple e Intel) } \\
\text { - Tecnologias e processos: ferramentas avançadas de bancos de dados } \\
\text { permitem que se conheça o cliente e se ofereça o produto que mais atendas } \\
\text { às suas necessidades. Quanto maior a capacidade de armazenamento e } \\
\text { organização da informação, e mais eficiente os sistemas de codificação e de } \\
\text { busca, maiores serão as chances de agradar o cliente e atender suas } \\
\text { expectativas } \\
\text { - Capital intelectual: as vendas de licenças e patentes, uma vez que seus } \\
\text { custos de desenvolvimento forem cobertos, trazem retornos mais altos, já que } \\
\text { têm custos de produção são mínimos - os produtos já foram criados. Produtos } \\
\text { como softwares, por exemplo, praticamente não envolvem custo de venda e } \\
\text { não enfrentam problemas como estoque e logística. } \\
\text { - Comunicação e transparência: a maneira como a empresa comunica suas } \\
\text { mensagens corporativas e as características de seus produtos e serviços pode } \\
\text { gerar credibilidade ou dúvidas. É preciso ser transparente e estar atento às } \\
\text { diferentes mídias, as mudanças de comportamento e às particularidades } \\
\text { culturais. É preciso passar a mesma mensagem, adaptando-se linguagem e } \\
\text { meios de acordo com públicos, sem esquecer que estão todos conectados }\end{array}$ \\
\hline $\begin{array}{l}\text { b) reduzir custos } \\
\text { de venda }\end{array}$ & $\begin{array}{l}\text { - Tecnologias e processos: comércio eletrônico, atendimento online, } \\
\text { serviços via internet, treinamentos em base web eliminam a necessidade de } \\
\text { espaço físico para realizar o negócio } \\
\text { - } \quad \text { Redes e alianças estratégicas: as redes e alianças eliminam a necessidade } \\
\text { de aquisição de muitos equipamentos, já que não será mais necessário } \\
\text { produzir todos componentes do produto final } \\
\text { - Inovação: soluções inovadoras podem eliminar etapas do processo de } \\
\text { produção, reduzindo os custos relacionados àquela etapa (peças, pessoas, } \\
\text { máquinas, entre outros) } \\
\text { - Capital intelectual: licenças e patentes, uma vez desenvolvidas, } \\
\text { praticamente não envolvem custo para serem produzidos (exemplo: } \\
\text { softwares, filmes, remédios) } \\
\text { - Cultura e Organização do ambiente de trabalho: a estrutura da empresa } \\
\text { pode otimizar processos, ao permitir o compartilhamento e/ou revezamento } \\
\text { de materiais, equipamentos e pessoal } \\
\text { - Adaptabilidade: a descentralização e a flexibilidade da estrutura facilitam a } \\
\text { interação entre as pessoas, as trocas de informações, o reconhecimento das } \\
\text { competências e habilidades e, portanto, a agilidade de lidar com situações } \\
\text { mutantes ou de crise }\end{array}$ \\
\hline $\begin{array}{l}\text { c) reduzir } \\
\text { despesas } \\
\text { operacionais } \\
\text { comerciais e } \\
\text { administrativas }\end{array}$ & $\begin{array}{l}\text { - Cultura e Organização do ambiente de trabalho: empresas cujos } \\
\text { departamentos compartilham e/ou revezam materiais, equipamentos e } \\
\text { consultores conseguem reduzir despesas operacionais } \\
\text { - Tecnologias e processos: novas tecnologias permitem procedimentos mais } \\
\text { eficientes e eficazes, possibilitando redução de despesas operacionais como } \\
\text { comunicação interna entre os funcionários e necessidade de espaço para } \\
\text { estocagem e armazenamento de materiais. Ao automatizarem processos } \\
\text { existentes é possível redesenhar a folha de pagamentos. Novas tecnologias } \\
\text { trazem ainda soluções mais inteligentes em relação, por exemplo, ao } \\
\text { consumo de energia. Tecnologias de comunicação e localização GPS permitem } \\
\text { controlar frotas e melhorar sistemas de logística, reduzindo ainda necessidade } \\
\text { de espaço de estoque }\end{array}$ \\
\hline
\end{tabular}




\begin{tabular}{|c|c|}
\hline & $\begin{array}{l}\text { - Capital intelectual: softwares, por exemplo, permitem que se amplie o } \\
\text { número de atendimentos sem necessariamente aumentar a folha de } \\
\text { pagamento e, consequentemente, estrutura física. É o caso, por exemplo, de } \\
\text { sistemas de reserva de passagens aéreas pela Internet. } \\
\text { - Inovação: a inovação, quando relacionada às despesas operacionais, está } \\
\text { ligada diretamente ao capital intelectual e tecnologias e processos. Empresas } \\
\text { inovadoras influenciam a criatividade, e portanto a criação de novas soluções, } \\
\text { que tornam os processos da organização mas eficazes } \\
\text { - Capital humano: ao reter seus profissionais, a empresa reduz despesas } \\
\text { com serviços de recrutamento, por exemplo. Ainda, funcionários satisfeitos, } \\
\text { mesmo que optem por trabalhar em outras empresas, dificilmente entrarão } \\
\text { na justiça do trabalho, o que reduz despesas operacionais na área jurídica } \\
\text { - } \quad \text { Adaptabilidade: quando a gestão é orientada por processos e produtos, a } \\
\text { equipe diretamente envolvida está mais próxima dos problemas e soluções } \\
\text { relativas à rotina de suas atividades e áreas afins. Essa proximidade permite } \\
\text { que se acelere o conhecimento de novas formas de se conduzir os negócios, e } \\
\text { acompanhar a mudanças de mercado. Relacionada ás despesas operacionais, } \\
\text { a capacidade de adaptação está ligada à capacidade de acompanhar as } \\
\text { mudanças gerenciais e à flexibilidade das estruturas, que podem, por } \\
\text { exemplo, evitar despesas fixas } \\
\text { - Liderança: os comportamentos dos líderes influenciam o comportamento } \\
\text { dos demais funcionários. Gastos desnecessários com materiais de escritório, } \\
\text { má conduta em relação ao desperdício de energia e falta de consciência } \\
\text { ambiental são multiplicados pelo número de pessoas que seguem sua } \\
\text { conduta, por exemplo } \\
\text { - Responsabilidade social e ambiental: quando os funcionários incorporam } \\
\text { o conceito de consumo consciente, desperdícios de água, papel e energia } \\
\text { deixam de existir } \\
\text { - Comunicação e transparência: a comunicação interna reduz trabalhos } \\
\text { redobrados ou re-trabalhos por falta de conhecimento, por exemplo. Os } \\
\text { procedimentos corporativos, se bem conhecidos, reduzem o tempo gasto por } \\
\text { cada funcionários na busca de informações }\end{array}$ \\
\hline $\begin{array}{l}\text { d) reduzir } \\
\text { pagamentos de } \\
\text { juros } \\
\text { (alavancagem } \\
\text { financeira) }\end{array}$ & $\begin{array}{l}\text { - Reputação: empresas com boa reputação têm mais credibilidade e têm } \\
\text { maiores chances de conseguir taxas de juros mais baixas } \\
\text { - Capital humano: profissionais competentes na área financeira têm } \\
\text { melhores condições de avaliarem sistematicamente o ponto ótimo entre } \\
\text { dívida e capital próprio }\end{array}$ \\
\hline $\begin{array}{l}\text { e) reduzir } \\
\text { investimentos } \\
\text { em ativos fixos }\end{array}$ & $\begin{array}{l}\text { - Redes e alianças estratégicas: permitem que sejam combinadas } \\
\text { competências de forma que não seja preciso manter equipes, estruturas e } \\
\text { equipamentos fixos para realizarem atividades que não estejam diretamente } \\
\text { relacionadas ao core business da empresa, e portando não são demandadas } \\
\text { rotineiramente } \\
\text { - Cultura e Organização do ambiente de trabalho: empresas que adotaram, } \\
\text { ou incentivam o home office reduzem as necessidades de se manter espaços } \\
\text { físicos de trabalho. Ambientes virtuais de trabalho reduzem necessidade de } \\
\text { estruturas físicas montadas, como acontece com lojas que comercializam seus } \\
\text { produtos somente pela Internet } \\
\text { - Tecnologias e processos: a convergência de tecnologias reduzem cada vez } \\
\text { mais a quantidade de equipamentos necessários para a realização das } \\
\text { atividades. A manutenção de sistemas de gestão integrada como o SAP } \\
\text { (Systems, Applications and Products in data processing) reduzem a }\end{array}$ \\
\hline
\end{tabular}




\begin{tabular}{|c|c|}
\hline & $\begin{array}{l}\text { necessidade de equipes inteiras, e consequentemente estruturas e } \\
\text { equipamentos. } \\
\text { - Capital intelectual: Sistemas de gestão integrada como o SAP reduzem a } \\
\text { necessidade de equipes inteiras, e consequentemente estruturas e } \\
\text { equipamentos fixos }\end{array}$ \\
\hline $\begin{array}{l}\text { f) aumentar } \\
\text { capital de giro } \\
\text { Aumentar o } \\
\text { capital de giro } \\
\text { implica, } \\
\text { automaticamente } \\
\text { em: } \\
\text { - Aumentar } \\
\text { ativo } \\
\text { circulante } \\
\text { - Reduzir } \\
\text { passivo } \\
\text { circulante }\end{array}$ & $\begin{array}{l}\text { - Capital humano: profissionais competentes nas áreas administrativa, } \\
\text { contábil e financeira têm melhores condições de avaliarem sistematicamente } \\
\text { o ponto ótimo da dívida, traçarem estratégias de aplicação financeira e } \\
\text { formatarem um planejamento tributário. Junto com os profissionais das áreas } \\
\text { comercial e operacional podem, também, negociarem prazos com os } \\
\text { fornecedores de forma que os períodos entre pagamentos sejam suficientes, } \\
\text { por exemplo, para realizarem aplicações financeira } \\
\text { - Reputação: a boa reputação junto a fornecedores pode significar maior } \\
\text { credibilidade, e, portanto, maior flexibilidade em relação aos prazos e formas } \\
\text { de pagamento } \\
\text { - Cultura e Organização do ambiente de trabalho: empresas que delegam } \\
\text { poderes a funcionários e permitem que eles conheçam o que está } \\
\text { acontecendo pode ficar atualizada em relação à novos fornecedores e novas } \\
\text { tecnologias. Especialistas têm melhores condições de avaliarem as reais } \\
\text { necessidades de estoques e serviços terceirizados em suas áreas de } \\
\text { competência e julgarem valores de mercado. Essas informações impactarão, } \\
\text { por exemplo, os orçamentos dos fornecedores } \\
\text { - Liderança: a liderança relacionada ao aumento de capital de giro está } \\
\text { diretamente relacionada a cultura e ambiente de trabalho. Líderes que } \\
\text { envolvem os profissionais especialistas nas tomadas de decisões, sobretudo } \\
\text { em relação à contratação de serviços, podem conseguir melhores resultados } \\
\text { em relação a prazos e valores com os fornecedores }\end{array}$ \\
\hline
\end{tabular}

Quadro 2: como os ativos intangíveis podem contribuir para aumentar o valor das empresas

Fonte: elaborado pela autora

Algumas dessas medidas impactarão simultaneamente o valor econômico e o contábil, como é o caso do aumento do faturamento e redução de despesas. Outras têm influência maior no valor econômico da empresa, e são as principais responsáveis pelas diferenças entre o valor patrimonial e o valor econômico calculado por Fluxo de Caixa Descontado. É o caso das análises dos componentes que influenciam o valor do beta - o tipo de negócio, a alavancagem operacional e a alavancagem financeira. A figura 3 indica que medidas influenciam os resultados contábeis e econômicos simultaneamente e quais têm peso maior no valor econômico. 


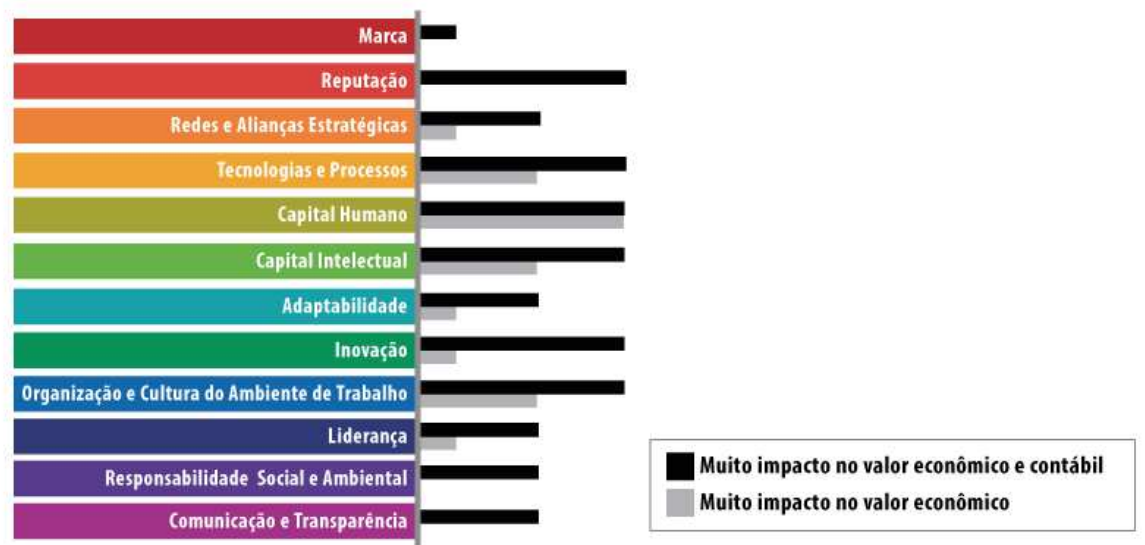

Figura 2: Contribuição dos intangíveis no incremento de valor

Fonte: elaborado pela autora

Ao relacionar a influência das medidas para incremento de valor e a contribuição dos intangíveis, percebe-se que os principais responsáveis pela diferença entre o valor econômico e o contábil são: as redes e alianças estratégicas, as tecnologias e processos, o capital humano, o capital intelectual, a adaptabilidade, a inovação, a organização e cultura no ambiente de trabalho e a liderança (figura 3).

Embora seja clara a influência do investimento em ativos intangíveis no incremento de valor da empresa, é também importante saber mensurá-la. Analisando-se as características de intangíveis e seu papel no mercado globalizado, e o valor econômico de uma empresa, tem-se que:

- O valor de mercado de uma empresa deve refletir a sua capacidade de geração de riqueza no futuro;

- Os investimentos em intangíveis hoje, muitas vezes contabilizados nos balanços como despesas, quando bem-sucedidos geram benefícios no futuro geralmente com baixos custos de operação;

- A relevância do papel dos intangíveis foi impulsionada sobretudo pela pressão do mercado globalizado, que demandou mudanças na forma de como as empresas funcionam, ou seja, na organização e cultura do ambiente de trabalho;

- A aceleração das mudanças, provocadas pelas novas tecnologias e meios mais eficazes de comunicação fizeram com que a capacidade de inovação e adaptação se tornassem essenciais para a sobrevivência da empresa;

- A inovação é impulsionada por estruturas organizacionais que propiciam os talentos a desenvolverem, com a ajuda de ferramenta tecnológicas avançadas, novas soluções de produtos, serviços e processos; e

- Marcas fortes e monopólio em um segmento de mercado possibilitam o aumento do preço cobrado e o estabelecimento de barreiras a concorrentes, afetando diretamente os resultados financeiros da empresa.

Ora, se o objetivo é gerar riqueza no futuro, a ameaça maior é a falta de capacidade de acompanhar as mudanças, o que enfraquece a competitividade. A criação de valor depende em grande parte de soluções inovadoras, geradas por recursos humano competentes e preparados, em uma estrutura organizacional adequada e tecnologia acessível. Essas soluções, quando comercializadas geram os retornos financeiros. Então, 
pode-se dizer que, acima dos três fatores geradores de dos intangíveis citados por Baruch Lev - recursos humanos, estrutura organizacional e inovação - está o fator sustentabilidade, que afetará exatamente a possibilidade da empresa sustentar a sua capacidade de manter-se competitiva (figura 4). Ou seja, a sustentabilidade dos negócios vai impactar diretamente a perpetuidade da empresa.

A sustentabilidade empresarial, tecnicamente, pode ser definida como a possibilidade de uma empresa garantir a sua continuidade, auferindo com as suas próprias atividades os recursos necessários para financiá-las.

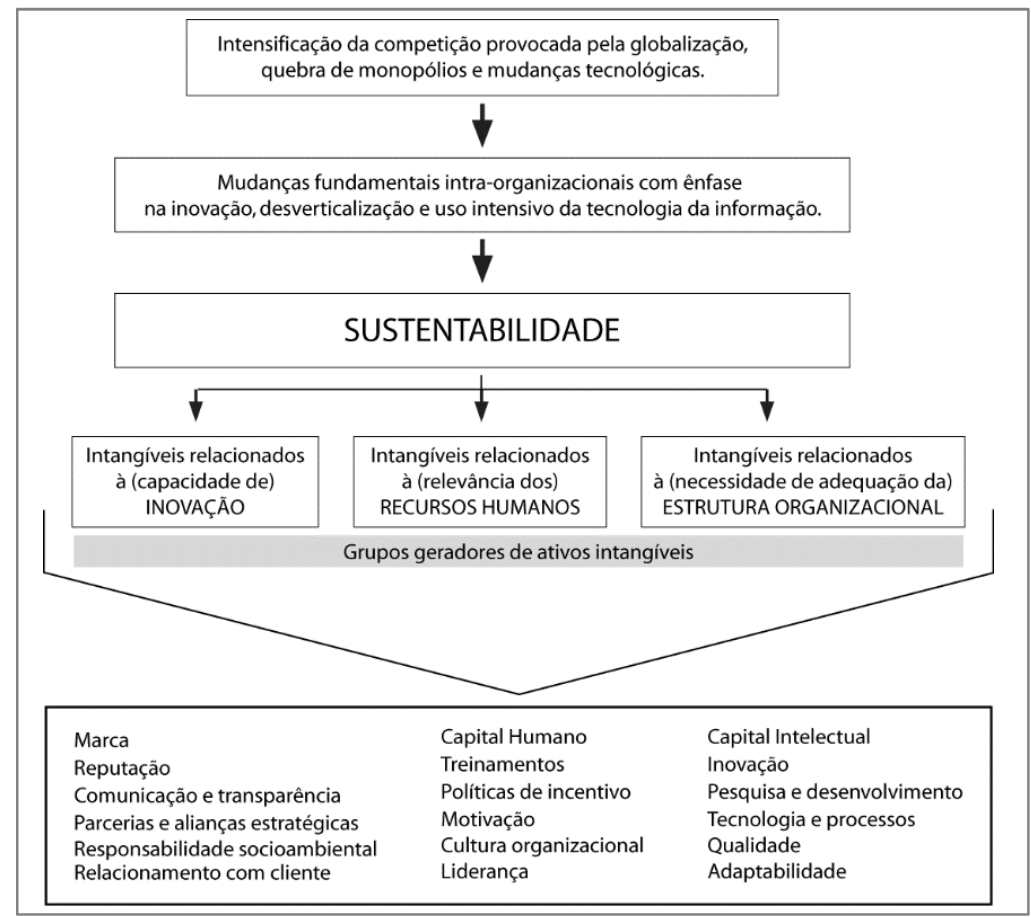

Figura 3: Sustentabilidade e as categorias de intangíveis de Baruch Lev Fonte: adaptado pela autora de Baruch Lev, 2001

Para uma empresa compor o índice de sustentabilidade empresarial da bolsa de valores, ela é submetida a um questionário que abrange três dimensões: econômica, ambiental e social.

O Índice Dow Jones de Sustentabilidade (DJSI) foi o índice utilizado neste trabalho para se analisar a relação entre os indicadores e os ativos intangíveis pelos seguintes motivos: 1) é o mais antigo; 2) tem presença global (empresas de diferentes países compõem o índice); e 3) o questionário é divulgado com os pesos correspondentes a cada pergunta, o que possibilita ponderar a representatividade dos intangíveis no conjunto.

De acordo com a análise, os doze intangíveis são contemplados nos indicadores de sustentabilidade da Dow Jones. Alguns deles, como as redes e alianças estratégicas têm menor influência na sustentabilidade empresarial. Já a reputação, o capital humano, a responsabilidade social e ambiental e a comunicação e transparência exercem influência sobre a maioria das questões e requerem, pois, atenção especial na gestão. $A$ figura 5 resume as informações sobre a presença dos intangíveis na avaliação da sustentabilidade empresarial. 
Resumindo, a influência dos intangíveis sobre o valor das empresas pode assim ser descrito: os valores contábeis e econômicos das empresas são muito influenciados pelos intangíveis reputação, tecnologias e processos, capital humano, capital intelectual, inovação e organização e cultura do ambiente de trabalho. Já os intangíveis: capital humano, tecnologias e processos, organização e cultura do ambiente de trabalho e tecnologias e processos têm ainda potencial de alavancar o valor econômico e aumentar o valor de mercado da empresa, independentemente de seu valor contábil. Mas para manter as previsões, torna-se fundamental avaliar a sustentabilidade empresarial, que é altamente influenciado pela reputação, o capital humano, a responsabilidade social e ambiental e a comunicação e transparência.

Além disso, durante a análise foi verificado que os intangíveis não podem ser avaliados isoladamente, pois eles influenciam uns aos outros. Analisando-se as influências sofridas e exercidas, percebe-se que alguns intangíveis têm muita influência sobre os demais, como é o caso da inovação, liderança e comunicação e transparência. Negligenciá-los, além dos impactos individuais, pode comprometer o desempenho dos demais ativos.

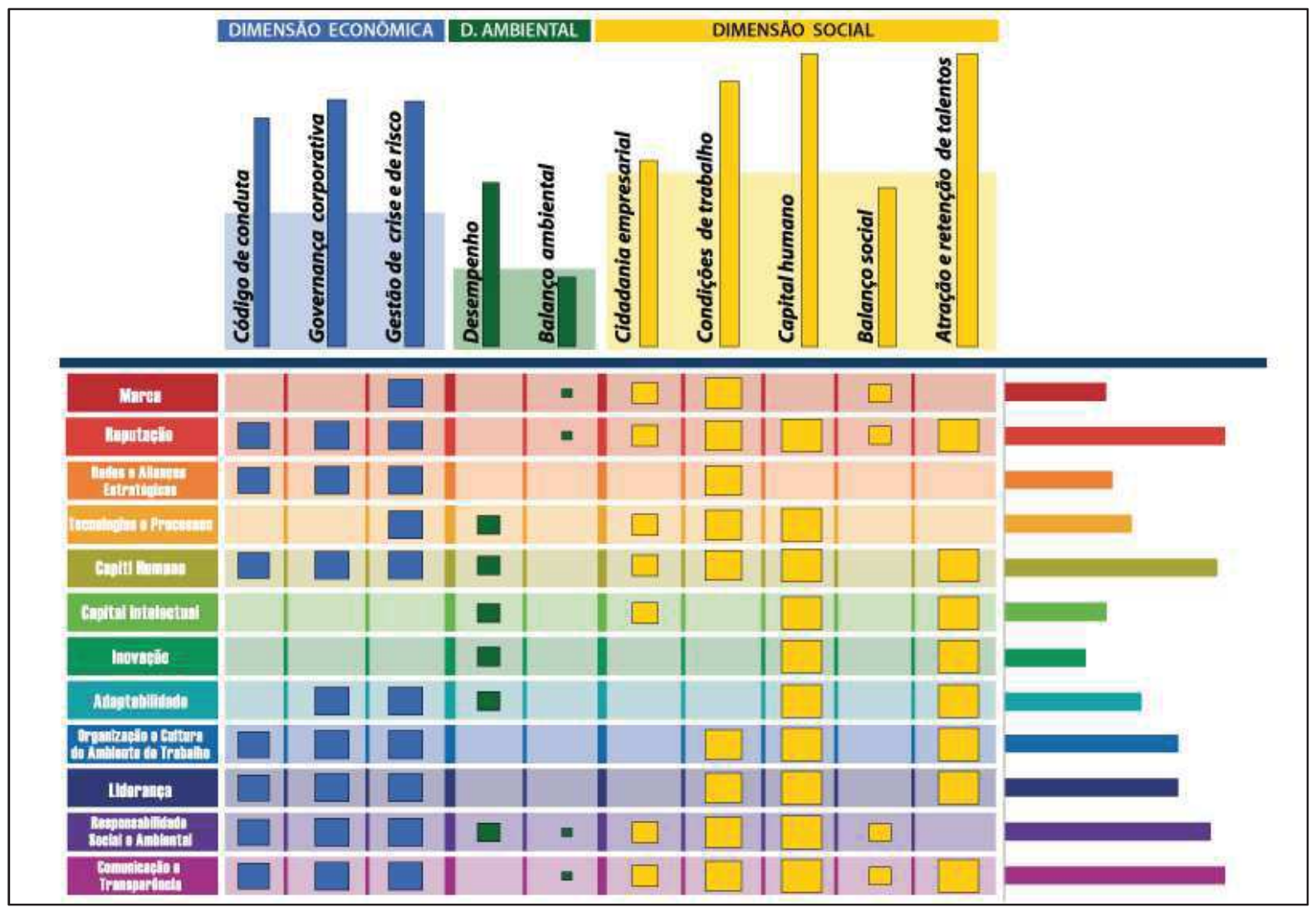

Figura 4: DJSI (dimensões, indicadores e pesos) e influência dos intangíveis

Fonte: elaborado pela autora

Por exemplo, muitas empresas investem valores altos em campanhas publicitárias com o objetivo de melhorarem suas imagens e fortalecerem suas marcas. Um discurso vazio, no entanto, não trará o resultado almejado. A marca é um dos intangíveis que mais sobre influência dos demais. A construção de uma marca forte requer atenção, avaliação, investimento e gestão de: redes e alianças estratégicas firmadas com empresas que 
contribuam para reduzir o impacto da concorrência e aumentar a qualidade da oferta; novas tecnologias capazes de manter uma melhora contínua dos produtos, serviços e atendimento; motivação e retenção de pessoal, a fim de aumentar a produtividade e evitar que troquem de empresa e levem aos concorrentes estratégias e metodologias da empresa; geração de conhecimento e comercialização de produtos inovadores, de acordo com as necessidade e desejos do mercado; capacidade de manter-se atualizado e apto a evitar e/ou enfrentar crises; admiração e respeito dos funcionários acerca da cultura e ambiente de trabalho da empresa, uma vez que são eles os principais condutores de mensagens sobre as organizações onde trabalham; compromisso com os problemas ambientais enfrentados mundialmente e com o desenvolvimento humano; atenção ao consumidor consciente, que pode não apenas rejeitar o produto ou serviço, mas iniciar um movimento contrário a empresa; e por fim, comunicar aos stakeholders da empresas as iniciativas, as ações, os resultados, os fatos, as crises e as medidas adotadas para enfrentá-las, e outras notícias sobre a empresa, que certamente chegarão às partes interessadas por fontes diversas.

A figura 6 é uma matriz de intangíveis que relaciona as influências exercidas e sofridas por cada um deles, e tem como principal objetivo o auxílio na gestão destes ativos. A partir dela é possível mapear os investimentos que a empresa fez, faz e está pensando em fazer em intangíveis, e estabelecer as relações entre eles de forma que seja possível avaliar quais são as influências que podem potencializar ou inviabilizar o investimento. É possível ainda detectar que fatores estão prejudicando investimento já feitos e priorizar medidas e investimentos. Por exemplo, os líderes das empresas influenciam a cultura organizacional, motivam ou desestimulam as equipes, representam as empresas em situações diversas, e conferem à si próprios a responsabilidade de impactar a marca e reputação da companhia. A escolha do representante é, portanto, prioridade. A má escolha pode prejudicar investimento feitos em tecnologias e programas motivacionais, por exemplo.

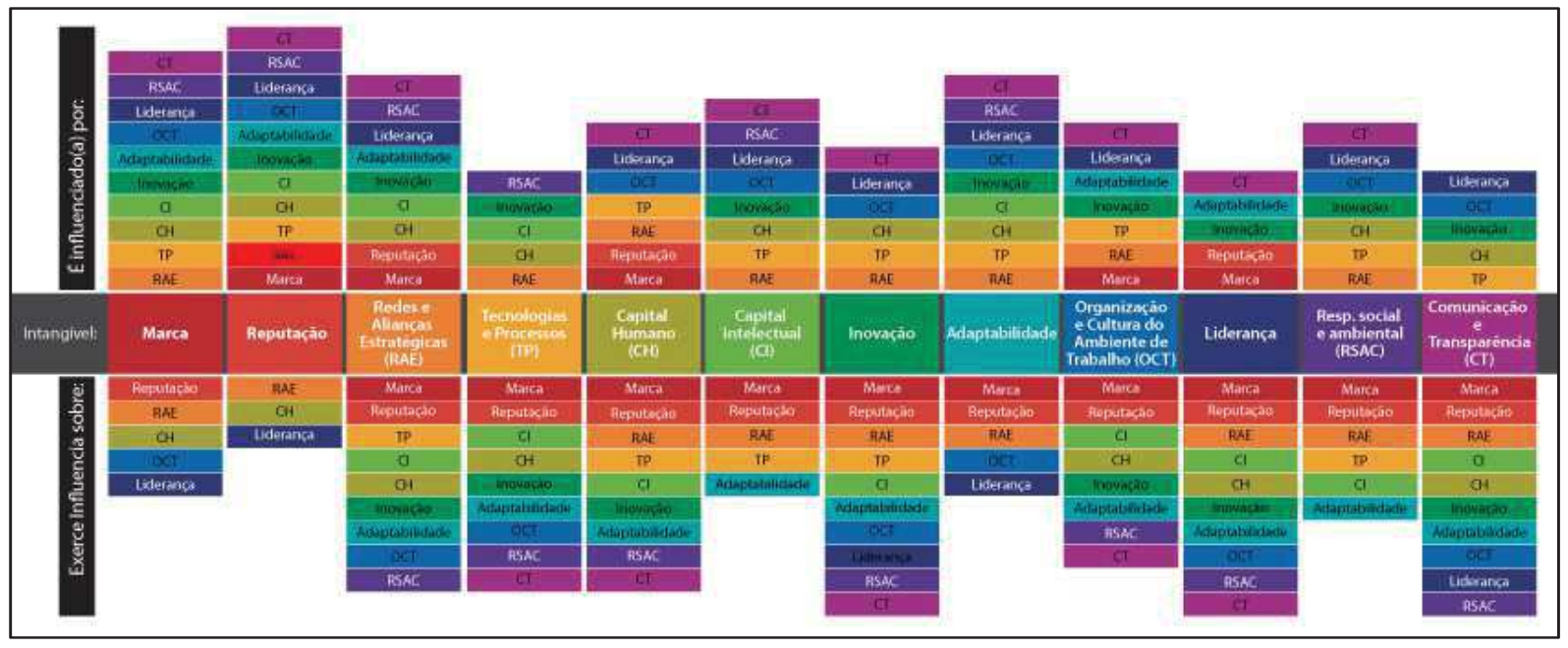

Figura 6: Influência dos intangíveis entre si

Fonte: elaborado pela autora

Ou seja, liderança, inovação e comunicação e transparência são os intangíveis que mais exercem influência sobre os demais. Já a reputação, a adaptabilidade, a marca e o 
capital intelectual são os mais dependentes, ou seja, os que mais sofrem influências. A figura a seguir ilustra essas relações: quanto maior a representação gráfica, maior a motricidade e menor a dependência do ativo. Inversamente, quanto menos, maior o grau de dependência dos demais.

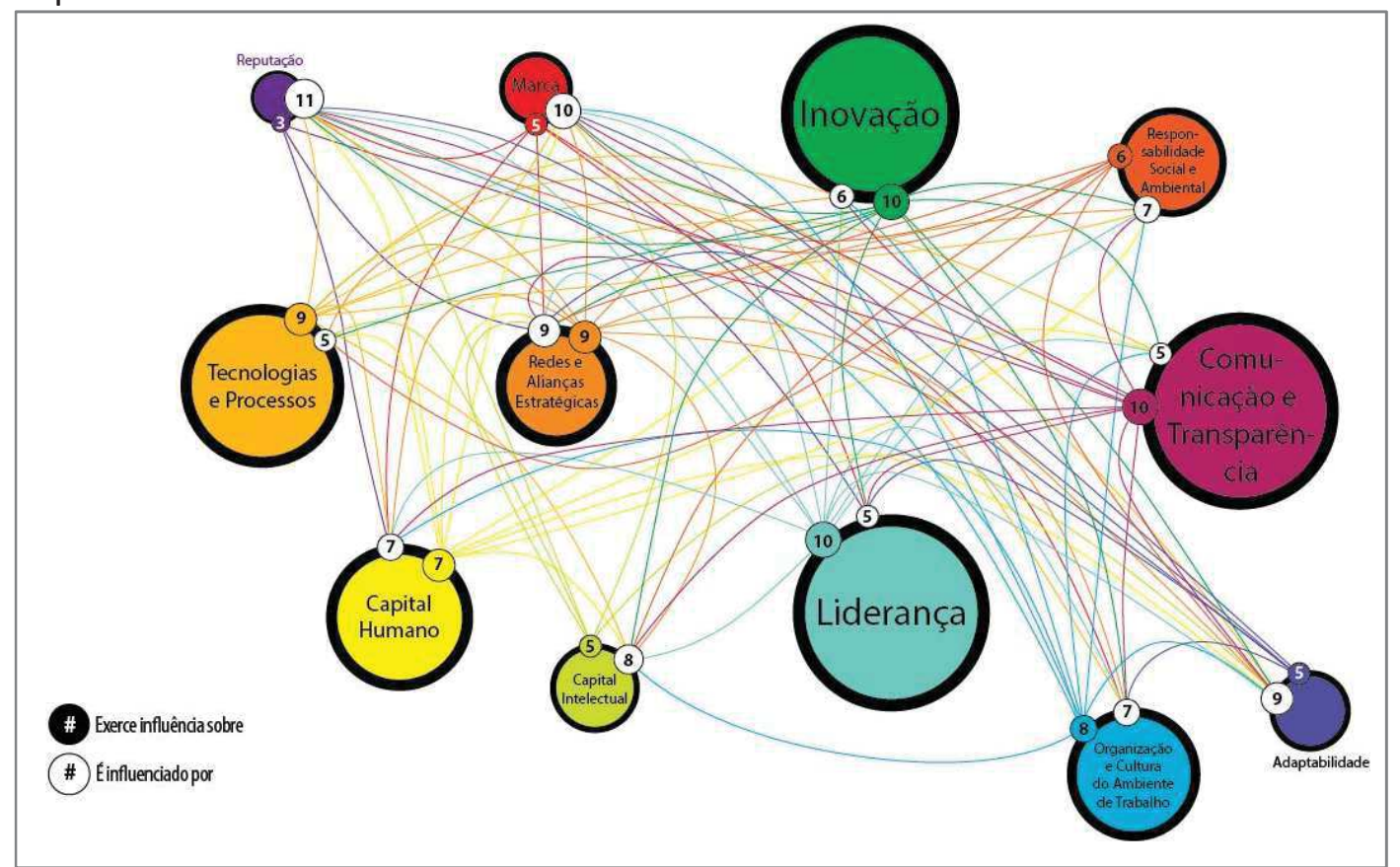

Figura 5: relação de influência entre os intangíveis

Fonte: elaborado pela autora

Trazendo essas informações para as análises de impacto no valor da empresa e na sustentabilidade empresarial, surge uma nova conclusão. Uma classificação ótima, por exemplo, é em grande parte impulsionada pelos intangíveis comunicação e transparência; responsabilidade social e ambiental, reputação e capital humano (figura 8).

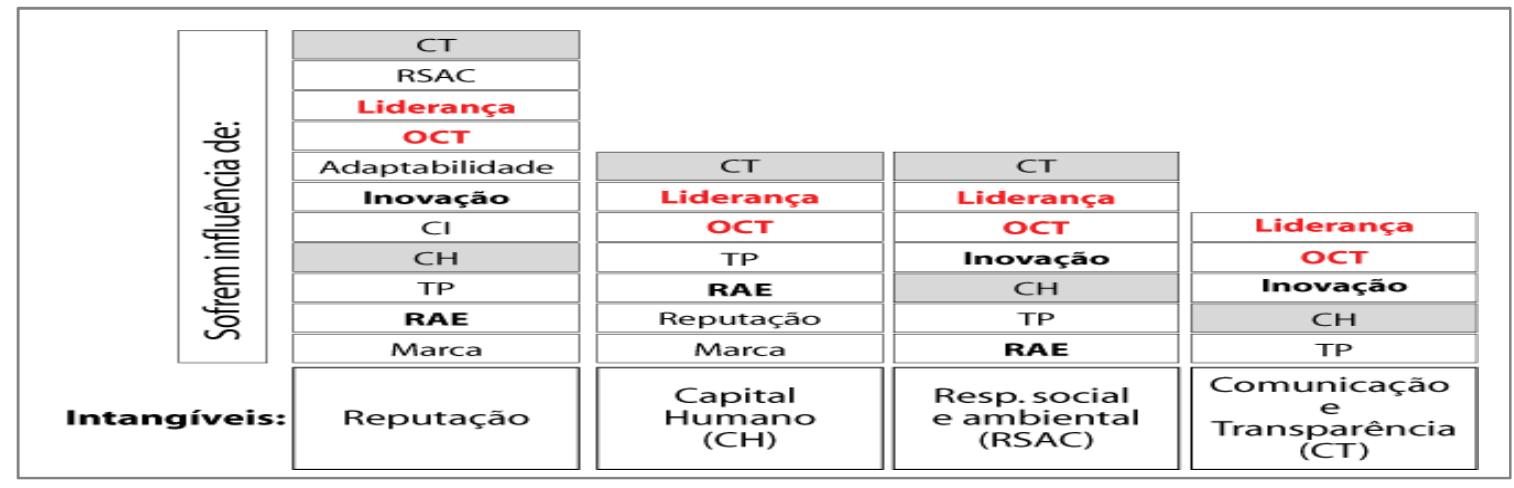

Figura 8: Influências sofridas pelos intangíveis prioritários do DJSI

Fonte: elaborado pela autora

Desses quatro intangíveis que mais impactam a sustentabilidade empresarial, todos têm impacto nos valores contábil e econômico da empresa, e o capital humano tem a 
capacidade ainda de potencializar a diferença entre os dois valores, aumentando ainda mais o valor da empresa. Todos os quatro sofrem ainda influência direta da liderança e organização e cultura no ambiente de trabalho.

\section{Conclusão}

Diversos métodos estão disponíveis para se avaliar empresas. Neste trabalho o foco foi dado à metodologia de Fluxo de Caixa Descontado, utilizada para se calcular o valor econômico da organização, que foi comparado ao seu valor contábil, verificado nas demonstrações contábeis. Enquanto este segundo pode ser considerado uma fotografia do atual momento da empresa, baseado em fatos e investimento ocorridos, o valor econômico fundamenta-se na projeção de resultados futuros. $E$, enquanto a contabilidade atribui ao goodwill a diferença entre os valores contábil e econômico, a proposta aqui foi entender como os ativos intangíveis trabalham para aumentar o valor da empresa e potencializar essa diferença. Ou seja, o que se buscou foi identificar como os intangíveis impactam o valor da empresa, e não apenas utiliza-los como justificativa para aquilo que não pode ser demonstrado contabilmente.

Ao optar-se por avaliar uma empresa utilizando-se como metodologia o Fluxo de Caixa Descontado a Valor Presente, está-se optando por avaliar as expectativas de resultados futuros, medidos pela capacidade de geração de caixa, e considerando-se os riscos associados, trazidos à valor presente por uma taxa de desconto apropriada. Obtémse assim o potencial de crescimento e perspectivas de rentabilidade futura.

Existem dois pontos importantes que merecem ser destacados:

a) alguns itens presentes na avaliação por Fluxo de Caixa Descontado podem ser impactados pela presença, ou ausência, de investimentos em alguns ativos intangíveis. Por exemplo, as redes e alianças estratégicas, a cultura organizacional, as tecnologias e processos e o capital intelectual podem contribuir para a redução de investimentos em ativos fixos. Já a marca, reputação, responsabilidade social e ambiental, inovação, redes e alianças estratégicas, tecnologias e processos, capital intelectual e comunicação e transparência podem contribuir para aumentar o faturamento. Outros exemplos foram apresentados no quadro 2.

b) Os intangíveis não podem ser trabalhados de forma isolada. Cada um deles influencia e sofre influência de outros intangíveis. Por exemplo, para conquistar uma boa reputação é preciso estar atento aos intangíveis: marca; redes e alianças estratégicas; tecnologias e processos; capital humano; capital intelectual; inovação; adaptabilidade; organização e cultura do ambiente de trabalho; liderança; responsabilidade social e ambiental; e comunicação e transparência. Inversamente, a liderança não depende de muitos intangíveis, mas tem poder de influência sobre a maioria deles. Ou seja, fortalecer um ativo intangível requer análise dessas influências e pode indicar investimento nele e/ou em tantos outros.

Em um mercado globalizado, com crescimento e avanços tecnológicos em ritmo acelerado, o grande desafio é acompanhar as mudanças e manter-se competitivo. Ou seja, o desafio reside, em grande parte, no fator sustentabilidade, que influencia exatamente a possibilidade da empresa sustentar sua capacidade de geração de riqueza. Neste cenário, os índices de sustentabilidade empresarial criados pelas bolsas de valores podem ajudar a mostrar quais empresas estão melhores preparadas para lidar com as mudanças, sem perder a estabilidade necessária para manter suas operações. Para 
compor um índice de sustentabilidade é preciso cumprir com uma série de requisitos que, por si só, já demonstram maior preparo para manter-se em atividade, mesmo em situações adversas. As empresas que compõem índices dessa natureza devem ser vistas de forma diferenciada, e devem ter essa condição refletida em seus valores. Da mesma forma, empresas que tiveram pontuação ótima nos questionários devem ser tratadas de forma diferente das empresas que obtiveram a pontuação mínima requerida. Igualmente comparável é o tempo que a empresa integra o índice, ou seja, a capacidade de manterse nas mesmas condições. Ao analisar o questionário do Dow Jones Sustainable Index (DJSI), o mais antigo índice de sustentabilidade, percebeu-se que os ativos intangíveis podem exercer influência em todos as questões, em menor o maior grau.

A proposta deste trabalho foi identificar uma maneira de se contemplar os ativos intangíveis no valor de uma empresa, quando a mesma é avaliada pelo método de Fluxo de Caixa Descontado a valor presente. Em resposta ao problema de pesquisa, expresso por "de que forma os ativos intangíveis impactam o valor de uma empresa?", foi sugerido a criação de um prêmio pela sustentabilidade empresarial.

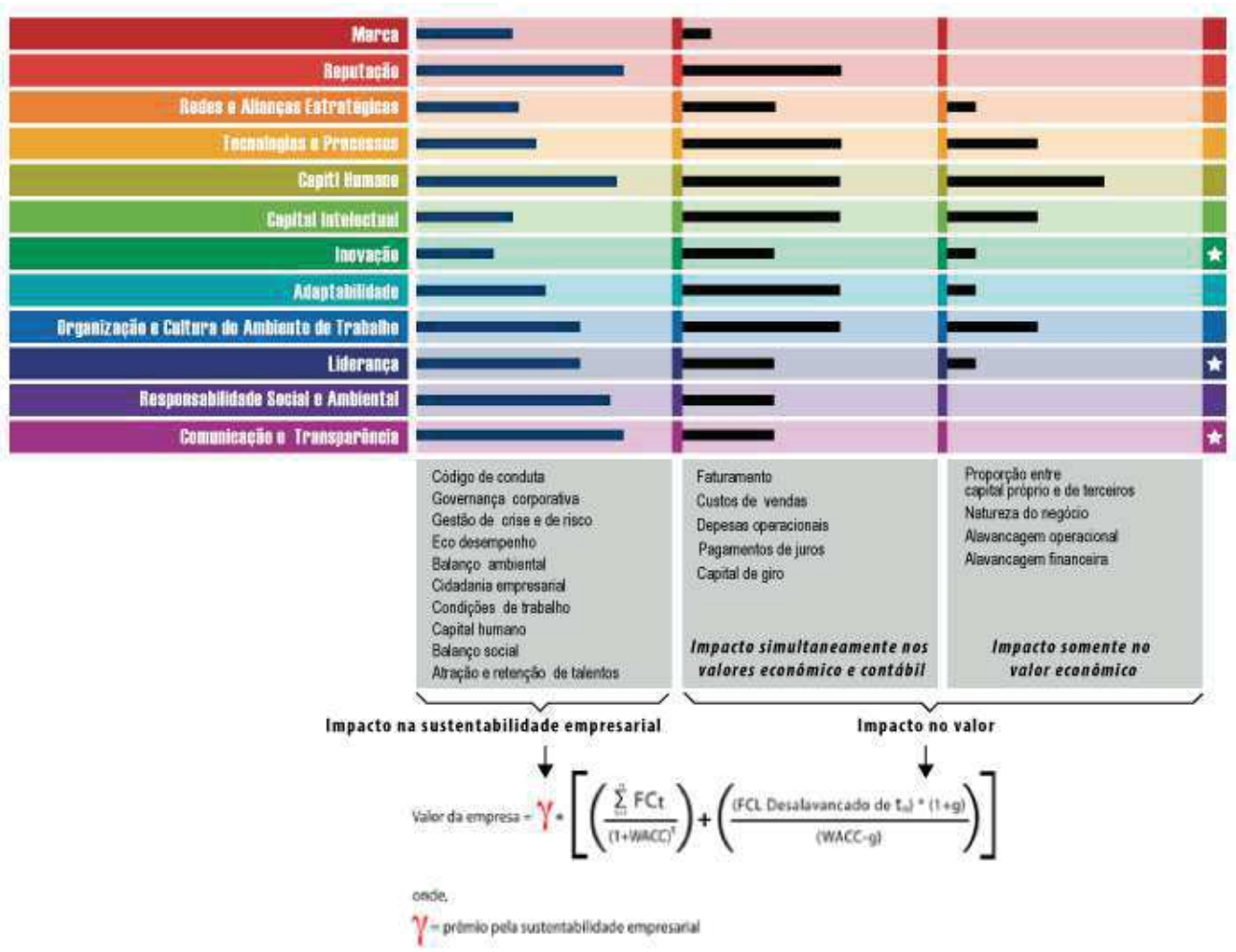

Figura 6: prêmio pela sustentabilidade empresarial

Fonte: elaborado pela autora

Assim, a proposta é a criação de um rating que sinalize o risco da sustentabilidade empresarial, a partir dos dados obtidos nos questionários do índice de sustentabilidade da bolsa de valores. As empresas devem ser classificadas de acordo com sua pontuação. Esta refletirá, portanto, o risco da sustentabilidade empresarial, ou seja, a probabilidade de não se conseguir sustentar suas projeções, considerando-se os aspectos econômico, social e ambiental. Deriva-se daí o prêmio pelo risco da sustentabilidade. Este novo componente deverá ser inserido no cálculo do valor da empresa pelo Fluxo de Caixa 
Descontado. O prêmio poderá seguir critérios semelhantes aos adotados pelas agências classificadoras, como exemplificado no quadro 3.

\begin{tabular}{|c|c|}
\hline \multicolumn{2}{|r|}{ Categoria de Investimento } \\
\hline AAA & $\begin{array}{l}\text { A mais alta classificação de sustentabilidade. A capacidade de manter-se } \\
\text { competitivo e sustentar as projeções de geração de riqueza, mesmo em cenários } \\
\text { inesperados e não planejados é muito alta. }\end{array}$ \\
\hline AA & $\begin{array}{l}\text { A capacidade de sustentabilidade é grande e pouco difere da classificação mais } \\
\text { alta. }\end{array}$ \\
\hline A & $\begin{array}{l}\text { A capacidade de sustentabilidade é alta, mas a empresa é suscetível a efeitos } \\
\text { adversos nas circunstâncias e condições econômicas, sociais e ambientais. }\end{array}$ \\
\hline BBB & $\begin{array}{l}\text { A capacidade de sustentabilidade é favorável, mas condições econômicas, sociais } \\
\text { e ambientais, ou circunstâncias adversas podem gerar risco. }\end{array}$ \\
\hline \multicolumn{2}{|r|}{ Categoria de Investimento de Risco } \\
\hline $\begin{array}{l}\text { BB / B } \\
\text { CCC -CC }\end{array}$ & $\begin{array}{l}\text { Uma classificação predominantemente especulativa, sendo BB a menos } \\
\text { especulativa e CC a mais especulativa. }\end{array}$ \\
\hline D & $\begin{array}{l}\text { A empresa encontra-se em situação altamente arriscada, não sustentável, ou com } \\
\text { atividades suspensas por motivos relacionados, por exemplo, a legislação } \\
\text { ambiental. }\end{array}$ \\
\hline
\end{tabular}

Quadro 3: descrição da classificação de sustentabilidade

Fonte: elaborada pela autora

Desta conclusão surgiu um novo problema de pesquisa, que parte da suposição de que a avaliação por fluxo de caixa deve considerar um prêmio pela sustentabilidade empresarial: como devem ser calculados os prêmios pela sustentabilidade empresarial?

\section{Referência Bibliográfica}

AAKER, David. Marcas - Brand Equity: gerenciando o valor da marca. São Paulo: Negócio, 1998.

BALDIN, Daniel. Como preparar seu plano de negócios para investidores de risco. Seminário da incubadora da empresa INETEC. Uberlândia-MG, setembro de 2003 In ZANDONADI, A. RUBEIRO, K., ROGERS,P. Avaliação através do método de Fluxo de Caixa Descontado livre de uma empresa de tecnologia da informação.

BANCO CENTRAL DO BRASIL. Risco-País. Série Perguntas Mais Freqüentes 2006. Disponível em http://www.bcb.gov.br

BANCO ITAÚ BBA S.A. Laudo de avaliação Aços Villares S.A. Fevereiro de 2006.

BERTERO, C. O administrador-líder. GVExecutivo. Vol.6 n.1 jan/fev 2007 p. 59 BNDES. Balanço Social e outros aspectos da responsabilidade social corporativa: Relato Setorial - AS/GESET n ${ }^{\circ}$ 2. Rio de Janeiro, 2005. $20 \mathrm{p}$.

BODIE,Z., MERTON, R. Finanças. Porto Alegre: Bookman, 2002. 
BOVESPA. Índice de Sustentabilidade Empresarial 2007 - Questionário Base. Disponível em http://bovespa.com.br

BUSINESS WEEK: Best Global Brands 2005. Usa: The Mcgraw-hill Companies Inc. 01 ago. 2005.

CALYLON CORPORATE FINANCE BRASIL. Laudo de Avaliação econômico-financeira: Copesul. Abril de 2007.

CANARIN, E., ROCHA, J.,PEREIRA, J. E VALENTE, P. A arte de comprar e vender empresas. Rio de Janeiro: Elsevier, 2007.

COMISSÃO EUROPÉIA. The intangible economy : impact and policy issues: report of the High level Expert Group on the intangible economy.In KALAFUT, P. \& LOW, J. Vantagem Invisível: como os intangíveis conduzem o desempenho da empresa. Porto Alegre:

Bookman, 2003, p.37.)

COMUNICARTE. Glossário Social. Rio de Janeiro: 2005

COPELAND, T., KOLLER,T.,MURRIN,J.Avaliação de empresas. São Paulo: Makron Books, 2000.

CREDIT SUISSE. Laudo de avaliação: Bunge Brasil SA. Maio de 2004.

CURY, M., SOUZA,C., GONÇALVES,D. e ABREU FILHO, J. Finanças Corporativas. 6ed. Rio de Janeiro: Editora FGV, 2005.

DAMOdARAN, A. Avaliação de Empresas. 2 ed. São Paulo: Pearson Prentice Hall, 2007. Finanças Corporativas: teoria e prática. Porto Alegre: Bookman,

2001.

DOW JONES. Dow Jones Sustainability Indexes. Disponível em

<http://www.sustainability-index.com/07_htmle/assessment/criteria.html

ENDLER, L. Avaliação de empresas pelo método de Fluxo de Caixa Descontado e os desvios causados pela utilização de taxas de descontos inadequadas. In Contexto. Porto Alegre, V.4,n.6, 2004.

FERNANDEZ, Pablo. Company valuation method. The most common errors in valuation. Madrid: IESE Business School, 2001. IN Zandonadi, 2004.

FERREIRA, A., REIS, A. e PEREIRA, M. Gestão empresarial: de Taylor aos nossos dias. São Paulo: Pioneira Thompson Learning, 2002.

GITMAN, L. Princípios de Administração Financeira. São Paulo: Addison Wesley, 2004. GOLDMAN SACHS INTERNATIONAL. Laudo de avaliação Arcelor Brasil S.A.. Outubro de 2006.

HARRINGTON, Diana R. Model Portfolio Theory, the capital asset pricing model \& arbitrage pricing theory: a user's guide. New Jersey: Prentice-Hall Inc., 1997. 
HOFMANN, J. Value Intangibles! Deutsche Bank Research: 19 de outubro de 2005. Disponível em: http://www.dbresearch.com

HSBC. Laudo de Avaliação econômico-financeira da Dana-Albarus S.A. Indústria e Comercio. Março de 2005

JUNG, C.G. O Homem e seus Símbolos. Rio de Janeiro: Nova Fronteira, 1997. p. 224

KALAFUT, Pam Cohen \& LOW, Jonathan. Vantagem Invisível: como os intangíveis conduzem o desempenho da empresa. Porto Alegre: Bookman, 2003.

KPMG. Pesquisa de Fusões e Aquisições 2007: Espelho das transações realizadas no Brasil. 2008. Disponível em www.kpmg.com.br

KWASNICKA, E. L., Introdução a Administração. São Paulo: Atlas, 2006, 6 Ed.

LEV, Baruch. Intangibles: Management, Measurement, and Reporting. Washington: The Brookings Institution, 2001.

The deteriorating usefulness of financial report information and how to reverse it. Accounting and Business Research, 48:5, 465-493, 2018. DOI:

10.1080/00014788.2018.1470138

MINTZBERG, H. Enough leadership. Harvard Business Review. V.82, n.11, nov/2004. In GVExecutivo. Vol.6 n.1 jan/fev 2007 p.

NAKAMURA, L.I., What is the US Gross Investment in Intangibles? (At Least) One Trillion Dollars a year.. In KALAFUT, P. \& LOW, J. Vantagem Invisível: como os intangíveis conduzem o desempenho da empresa. Porto Alegre: Bookman, 2003, p.35.)

PETROBRAS. Relatório Anual 2004. Rio de Janeiro, 2005. 128 p.

Balanço Social e Ambiental 2005. Rio de Janeiro, 2006. 156 p.

REIS DA SILVA, M. A determinação de valor econômico de uma empresa através do Fluxo de Caixa Descontado. Disponível em

http://www.unitau.br/nupes/artigos/det_valor_economico.htm

RIFIKIN, Jeremy. O Fim dos Empregos. São Paulo: Makron Books, 1995.

ROGERS, P., DAMI, A., RIBEITO, K. Fluxo de Caixa Descontado como método de avaliação de empresas: o estudo de caso da Petrobras Distribuidora S.A. In. XXIV ENEGEP, Florianópolis, 2004.

ROSS, S., WESTERFIELD, R., JAFFE, J. Administração Financeira. São Paulo: Atlas, 2002. Princípios de Administração Financeira. São Paulo: Atlas, 2002.

SCHMIDT, P., SANTOS, J. Avaliação de ativos intangíveis. São Paulo: Atlas, 2002. 
STEWART, Thomas. Capital Intelectual: a nova vantagem competitiva das empresas. Rio de Janeiro: campus, 1998.

UNIVERSIDADE DE SÃO PAULO (USP). Cidade do Conhecimento. Uma Nova matemática para uma nova economia. Entrevista com Baruch Lev, por Alan M. Webber realizada em 2006. Disponível em http://www.cidade.usp.br

VERGARA, Sylvia Constant. A liderança aprendida. GV Executivo. Vol.6 n.1 jan/fev 2007 p. 61 e 69 . Projetos e relatórios de pesquisa em administração. 7.ed. São

Paulo: Atlas, 2006. . Métodos de pesquisa em administração. São Paulo: Atlas,

2005.

WEIL e STICKNEY. Contabilidade Financeira. São Paulo: Atlas, 2001.

ZANDONADI, A. RUBEIRO, K., ROGERS, P. Avaliação através do método de Fluxo de Caixa Descontado livre de uma empresa de tecnologia da informação. In: Congresso Brasileiro de Custos, 2004. Porto Seguro. 2004 